\title{
Social Change and Individual Development in East Germany: A Methodological Critique
}

\author{
Gisela Trommsdorff
}

\section{Introduction: Social Change and Individual Behavior}

The unification of the two Germanys and the subsequent dramatic changes have not only changed the social, political and economic institutions in East Germany but also deeply affected the lives of the East German population. One can assume that the way these changes are experienced and accepted, and the way challenges and risks are coped with will, in turn, affect East German people's individual development and related social change in the future.

The unification of East and West Germany started in 1989 by formal transformation of East German institutions incorporating the West German system. However, the transformation process cannot be regarded as a socio-political process of only institutional change. Institutions need persons acting in these institutions, and implementing their aims. Therefore, institutional changes imply changes in individual behavior. The dramatic institutional changes in political, economic and social areas in East Germany require certain problem solving and coping strategies; and these may require behavioral changes of East German people and related motivation to acquire such behavioral competencies. Therefore, it should be asked whether these changes confront East Germans with new developmental tasks, and which kind of changes on the part of the individual person are necessary for dealing with these tasks, e.g., whether these changes imply changes in deeply rooted individual values, and other significant aspects of one's identity, or how costly it might be for the person to pursue changed patterns of development.

Though several studies have pointed out deficits in abilities of East German workers and managers (e.g., lower flexibility, lower readiness for initiative etc.), and how training programs can compensate for such deficits (e.g., Wottawa, 1994; Frese \& Hilligloh, 1994), these studies must not be misunderstood in the way that they provide lists of ideal values or personality traits required for successful coping during the transformation process in East Germany. Coping and successful outcomes are always a function of specific behavior fitting to specific environmental demands. This function bases on dynamic processes of matching individual needs, goals and behavioral competencies on the one hand, 
and environmental (social, political, economic, physical etc.) conditions, on the other hand.

Individual needs, behavior and the environment are not stable and can be changed in the course of individual development and in the course of the matching process. In order to satisfy certain needs and to obtain certain goals in the context of specific changes in the environment, the person can decide to learn certain behavior, and also can select certain responses from a repertoire of learned behavior. Therefore, it seems more adequate to study both in relation with each other: personal goals and abilities and their matching with environmental demands during interaction between both (cf. Friedlmeier, 1996; Trommsdorff \& Chakkarath, 1996). These adaptive processes in search for goodness-of-fit do not only characterize the process of individual development but also the process of social interactions and of individual coping in times of change.

Coping with stressful life events, necessary in times of drastic socio-economic change, would require psychological and social competencies of matching person-environment relations. Therefore, one may ask whether the transformation of the socio-economic environment in East Germany has induced certain changes in individual thinking and behavior, and whether these, in turn, have affected the social environment and the economic system of East Germany. Here, the question arises whether and in which way individuals can influence the kind and quality of social change. To give an example, significant changes in individual decision-making, life planning, and behavior can be seen in the drastic decline of marriage and fertility rates in East Germany during the last few years. So far, it is unclear whether these changes in individual decision making only reflect momentary adaptation processes to drastic economic and political transformation by postponement of certain life events and developmental tasks, or whether they are an indicator for substantial ongoing social and demographic change.

The more general question therefore is how social change is related to changes in individual behavior, and in individual development, and whether these, in turn, affect certain aspect of social change, e.g., productivity, fertility, status mobility, political activation, or socio-psychological unification. From an interaction process point of view, social change thus is related to individual development and change in the individual's behavior and thinking. So far, however, questions of social change have seldom been studied with respect to psychological questions, e.g., the question how social change may affect individual behavior, and vice versa, how individual behavior may affect the course of social change (cf. Flanagan, 1995; Elder, 1997 in press).

The present study attempts to view ongoing processes of transformation after the unification of the two Germanys from the point of view how individual development is linked to the cultural context and to related socio-policital changes. 
This question is part of the broader issue how - on the one hand - people adjust to their environment and to social changes, and - on the other hand - how people bring about social changes. In the following sections, we will first discuss some theoretical and psychological reasons for the interest in studying similarities and differences between East and West German people. Second, we will focus on some methodological problems in the study of similarities and differences. Finally, we will discuss in how far theoretical reasoning requires to complement "cross-cultural" studies by "acculturation" studies in order to account for individual development and social change from an interaction theoretical point of view.

\section{Theoretical and Methodological Issues in the Study of Similarities and Differences between East and West Germans}

\subsection{Limitations of "Social Address" Approaches and Differences between East and West Germans}

The specific interaction processes between the individual person and his/her socio-cultural and economic environment are very difficult to demonstrate empirically since such interactions take place on different levels (see Bronfenbrenner's, 1979 ecological model) and also with different speed and dynamics.

At first sight, a reasonable and simple approach seems to be the study of similarities and differences of people from (different socio-political contexts such as) East and West Germany, comparing mean values of attitudes and behavior, first at the beginning of the transformation process, then after such transformations have reached at least a phase of institutional consolidation, and continuing with further points of measurement during ongoing social change. This is what many surveys on value change do (e.g., IFD Allensbach, ALLBUS); these samples can be differentiated according to several variables like gender, age etc. Of course, all "social address" approaches suffer from the problem of disregarding relevant psychological variables while on the other hand, they are quite useful to measure general trends which then could be specified according to theoretically founded hypotheses.

The idea of studying the similarities and differences between East and West Germans is based on the assumption that about 40 years of socialization in different socio-political systems should affect people's thinking and behavior and therefore should account for differences between East and West German peoples though both have shared the same cultural environment for centuries. For 40 years, the socialization of children, youth and adults in both parts of Germany has differed enormously. In East Germany early-institutionalized socialization of infants was followed by training in school and at work according to the values 
of a socialist personality (cf. Schmidt, 1996; Weber, 1996). Differences in values, cognitive styles, and beliefs which have been demonstrated in several empirical studies on East and West Germans of different age (e.g., Schnabel, Baumert \& Roeder, 1994; Strohschneider, 1996) could be interpreted as effects of different socialization experience.

Have East Germans adopted the West German way of thinking and behavior after the collapse of the former GDR and subsequent formal unification of both Germanys, in order to be able to meet the newly established institutional requirements? The completely transformed socio-economic system clearly represents the values and beliefs of the majority. Differences between East and West Germany should then have slowly vanished on account of acculturation processes of East Germans. This assumption bases on quasi-experimental methodological thinking and a mechanistic (tabula rasa) model of human development underlying some comparative studies on East and West German people after the unification.

Simple comparisons of means at different points of time may give rise to wrong conclusions. This approach is based on the assumption that people behave according to the given environment: they are socialized in a certain environment; and when this environment changes (e.g., according to certain majority rules), people adapt to these changes (e.g., by accepting these majority rules).

From an interaction point of view, it seems more fruitful to study the way the individual relates to his/her context in the process of his/her development. Thereby certain values and behavior may be acquired by some East Germans who are more adequately fitting to the new context. These values may even seem to be similar to some West German people's behavior. But such similarities may only occur for a certain period of time, and only under specific conditions at another period of time; under different conditions they may not occur at all, or again seem to be different from West German people's behavior. An example may be the use of the same curriculum by East and West German teachers while performing different roles. East German teachers today would rather prefer to take the role of an "educator" than the role of an instructor as compared to West German teachers (cf. Kornadt, 1996). Another example for erroneously interpreting similarities is to take at face value data on value change. East Germans' increased preference of hedonism and leisure must not necessarily mean adaptation of West German values. E.g., significant differences in the quality of such leisure activities become apparent when comparing the social context of such activities. In East Germany, family and neighbors and in West Germany, private organizations of non-family members are the preferred social contexts.

In spite of methodological shortcomings, it still is quite useful to study similarities and differences between East and West Germans at different points of 
time in, e.g., values, political attitudes etc.). Comparative studies testing specific similarities and differences with respect to theoretically assumed relations between variables at different point of time should complete this comparative "cross-cultural" approach testing for effects of social changes and stabilities on individual development. Such studies, however, are incomplete without taking into account the subjective beliefs of the people under research (cf. Trommsdorff, 1994; 1995c; 1997 in press; Friedlmeier, 1996).

\subsection{Subjective Beliefs about Similarities and Differences}

Therefore, it is asked whether and how far empirical data based on objective methods demonstrating certain differences and similarities between East and West German's attitudes are matched by the subjective beliefs of West and East Germans on similarities and differences between the people from both regions.

It is a known phenomenon in social psychology that empirical data on observed behavior or attitudes of certain persons do not necessarily match with subjective beliefs about one's own behavior of these persons. Data on subjective beliefs about aspects of oneself and of other persons, and of perceived similarities or differences between oneself and other persons allow one to understand the subjective quality of interpersonal relation and the meaning of certain perceived differences for this relationship.

Social construction of differences and similarities is a typical phenomenon of intergroup differentiation and social stereotyping. Perceived differences are often evaluated by attribution of positive characteristics to one's own group, and by attribution of negative characteristics to the other group. Accentuation of differences between two similar groups is often based on a need for a positive social identity. This need is activated when one's own social identity has to be redefined on account of certain experiences of imbalance which may be induced by social changes (Taijfel \& Turner, 1986).

East German's coping with changes of institutions, presumably also includes redefinitions of social identity. The historical event of unification has not only changed Germany but may also have changed the psychological basis for anchoring the concept of social and national identity. Examples are nostalgic orientations in East Germany including identification with the former GDR and support for the PDS (Party of Democratic Socialism; former communist party). This process inctudes ways how subjectively perceived differences or similarities between East and West Germans are accentuated.

Data on national, regional and European identity right after the turnabout showed that West Germans' national identity included West Germans but not East Germans (Trommsdorff, 1995a). This fits in with results on auto- and hetero-stereotyping which showed that East and West Germans perceived more dif- 
ferences than similarities between each other (Schmitt \& Janetzko, 1994). In case there will be an increasing mutual perception of similarities of East and West Germans as reported by Noelle-Neumann (1995), it remains unclear whether this indicates increased "objective" similarities of East and West Germany, and what the basis of such judgements are. E.g., the degree of perceived similarities between one's own and another group may be attributed to successful modeling one's own beliefs and behavior according to the other person or group (secondary control), or to successful influence in changing the other person according to one's own preferred behavior (primary control). Depending on the quality of the relation between these persons or groups, attributions of primary or secondary control will prevail. These may carry a more or less positive meaning for the other group (or person) while at the same time providing selfenhancing effects and laying the basis for more or less cooperative and supportive (vs. conflicting) social interactions. Therefore, it is useful to ask whether East and West Germans view themselves as similar or rather as different, and furthermore, to study attributions for such perceptions. These attributions presumably are part of one's social identity. Here, more refined studies on social identity are needed, including data on the underlying value system, the anchoring of one's social identity, and the subjective perception of person-environment-relations before and after the turnabout.

\subsection{Goals and Limitations of Cross-Cultural Approaches}

Usually, comparative studies aim to test certain theories by using the chance to enlarge the variance of the relevant variables under study (independent or dependent measures) beyond the given variance in a certain cultural context. Thereby it is possible to apply stricter testing of the hypotheses, and also to control for otherwise confounded variables. Comparisons between East and West Germany allow studying both, differences and similarities with respect to theoretically interesting variables. Furthermore, hypotheses on the generality of such theoretically assumed relationships can be tested. Some scientists have seen the different political and economic systems in East and West Germany during the past 50 years and the dramatic turn-about of the political and economic system in East Germany after the unification as specific constellation in a quasi-experimental setting. Here, the focus can be on both: on effects of the different political system after the Second World War, and on effects of the turnabout on certain social psychological phenomena. Therefore, comparisons between East and West Gernan samples have sometimes been considered as a methodological advantage allowing for testing theories in a quasi-natural experimental design.

From a sociological point of view, it is of special theoretical interest to study the empirical validity of theories on modernization and institutional change, 
e.g., whether and what kind of modernization can take place in a non-democratic totalitarian system; whether East Germany can be seen as a latecomer in the process of modernization; how the functioning of incorporated institutions can be made effective; whether the socio-political development in East Germany after the unification affects the social system of Germany as a whole; whether certain value changes are universal in post-modern societies (e.g., Joas \& Kohli, 1993; Reissig, 1993; Mayer, 1993; Zapf, 1993; 1994).

From a psychological point of view, East-West German comparisons may provide the opportunity to test e.g., theories on socialization and individual development in a changing context. Theories of attachment could be tested under very different conditions - comparing children who have been growing up in contexts varying with respect to early-institutionalized childcare. Theories of identity formation could be tested comparing adolescents who have been growing up in contexts differing with respect to authoritarian values. Theories on successful aging could be tested by comparing persons who have been growing up in contexts of different importance of family orientation and informal social support.

More specifically, it has been asked which aspects of socialization in East and West Germany affect individual development in certain ways, and whether and in which way such developmental outcomes allow coping with changing developmental tasks in a changing socio-political context (cf. Trommsdorff, 1994).

However, only a very few empirical studies have been carried out to test such theories. Most studies have started from a more descriptive orientation searching for differences or similarities that then were interpreted on the basis of a broader theoretical framework. This includes most studies on socialization and individual development of children and adolescents in East vs. West Germany (for a summary see Trommsdorff \& Chakkarath, 1996). Also, broader theoretical questions as outlined by Schmidt and Heckhausen (1994) on different strategies of coping with the dramatic changes have rarely been empirically tested. Instead, most studies focused on descriptions of differences between East and West Germany. An advantage of such studies may be to specify hypotheses in how far differences between West and East Germans indicate difficulties or advantages of East Germans to cope with new demands in the West German system, and what the relevant variables are to improve the adaptation process.

In organizational psychology some research has been carried out to study whether and under which conditions East Germans accept the different economic system and adapt to its specific demands with respect to individual responsibility, leadership, problem-solving etc. in the context of work. Some of this research was implemented in training programs (cf. Wottawa, 1994; Frese \& Hilligloh, 1994) in order to increase similarities in qualification.

Studies dealing with the subjective experience of the dramatic social changes and coping processes are more or less implicitly based on the assumption that 
socio-political changes in East Germany constitute significant changes in the person's "life-space". Some of these changes may indeed imply critical life events, e.g., in case of losing life-long employment, or losing social support, security, and attachment in informal social networks, or losing social approval and influence in institutions (e.g., as former member of the socialist party). Here, problems of redefining important aspects of one's social and personal identity should arise (Trommsdorff, 1995b).

Beside the question, whether existing theories on coping and development can explain how individuals deal with such changes, it should be asked whether the methodological approach to compare East and West

Germans by focusing on their similarities and differences in a framework of a quasi-experimental approach is adequate, or whether it clouds more fundamental questions on processes of individual development and coping.

\section{Methodological Problems on Testing Social Change and Individual Development in East Germany in a Comparative Design}

\subsection{Semantic Meaning}

Some studies demonstrate differences and others demonstrate similarities between East and West German people. The question arises whether these data would be different if other methods were used and if other interpretations were employed. Here, methodological problems in cross-cultural studies become obvious.

The fact that people from East and West Germany have shared the same history until 1945, and also speak the same language, has often misled researchers to believe that the use of the same wording carries the same meaning in both parts of Germany. Certain expressions such as "Brigade" (team), "Solidarität" (solidarity), "Kampf" (fight); "Ausbildung" (education) carry a different meaning due to forty years of different political contexts in East and West Germany. Again, the meaning of some of these expressions has changed considerably since the unification. E.g., the expressions "solidarity" and "brigade" have now adopted a nostalgic emotional value for some East Germans since they reflect the informal social network at the workplace which is considered as a loss. Or "disco" had a different meaning directly after the turnabout for East and West German youth due to differential experience while the meaning may now be similar (Silbereisen, personal communication). Also, it is unclear from studies on value change in East and West Germany whether the decline in the value of "order" in East Germany indicates true change (e.g., due to adaptation of individualistic values) or whether it indicates changes in the use of semantics which are known to be negatively evaluated in West Germany. In a question- 
naire (or interview) the use of specific wording should therefore sometimes be complemented by further analyses to ascertain whether similarities in verbal stimuli are given.

\subsection{Single Item Analysis}

Furthermore, similarities or differences (of means) (e.g., the value of work, of ecological goals etc.) on single items do not mean much when these single variables are not studied as elements of a broader belief system. Such single items may have very different meanings in two cultural contexts even if they are preferred to the same extent by people from the two cultures. E.g., for East Germans the item "solidarity" means a rather emotional relationship in the former GDR based on mutual trust. Even if East and West Germans would place similar importance on this item, the emotional quality would be different. One can hardly compare "hot" and "cool" cognitions without losing important information; these may only be gained by comparing situational meanings including more than one item. E.g., Friedlmeier (1995) has shown that the value of "tolerance" is a highly relevant goal for Brazilian mothers even though they mention this goal less than German mothers do since it is so self evident for them. Statistical similarities of attitudes based on only one item regardless of whether it is part of a respondent or a non-respondent verbal instrument cloud the fact of substantially different meanings which can only be discovered by studying the interrelations between items, or the position of this specific item within a psychologically relevant pattern of attitudes and beliefs.

Misinterpretations concerning similarities and differences of single values are abounding. Asking for the value of "autonomy" and "independence" can produce the same means in East and West Germany. This only suggests that postmodern values are preferred in a similar way even though the value of autonomy has a different meaning for East and West German parents due to the fact that its relation to other post-modern values (e.g., individuality, self-fulfillment etc.) is not the same. This, however, can only be seen when the cultural context or at least other parts of this value system are also taken into account (see Trommsdorff, 1996a).

This disadvantage of single item analyses can be compared with problems of generalized personality traits. Singe variables measuring values or goals of socialization such as "independence", "honesty", "diligence" etc. are not useful since the context in which such variables are embedded remains completely unclear. For instance, in East Germany, to be honest was a true value for children's socialization; however, a clear differentiation was implicitly made between being honest towards family and peers vs. towards authority figures or representatives of governmental institutions. Therefore, in case of comparative 
studies, at least situational contexts in which values such as independence are socialized must be taken into account (cf. Trommsdorff, 1996a). To give another example, in our own research on development of pro- and antisocial motivation in East and West German adolescents, we started from the assumption that secure attachment is related to the development of more pro- and less antisocial motivation. Also, we assumed that the early institutionalization of infants and early separation from their mothers in East Germany would impair secure attachment in contrast to West German children assuming that other important variables (e.g., quality of child care and mother-child relation) remain constant. We did not find significant differences in the attachment scores when comparing mean values; however, we found interesting relations between attachment and social motivation. Securely attached East as compared to West German adolescents (as measured by the Adult Attachment Scale (AAS) (Hansburg, 1972) showed no relation to aggression (Saarbrücken Aggression Scale, SAS) (Pearson-correlation test) while for West German adolescents secure attachment was negatively related to aggression $(\mathrm{r}=-.30, \mathrm{df}=79, \mathrm{p}<.01)$ as was predicted by the theory of attachment. Also, for East German adolescents, no correlation between separation anxiety and aggression occurred while for West German adolescents a significantly positive correlation was shown $(\mathrm{r}=.37 \mathrm{df}=79, \mathrm{p}$ $<001$ ) (cf. Trommsdorff \& Kornadt, 1995). Thus, it seems that either our attachment measure was not appropriate for East German adolescents, or that for certain reasons the theoretically predicted relations between attachment and aggression holds for West but not for East German youth.

Another example is that in economic hardship, culturally different patterns of coping can occur. Depending on the subjective experience of developmental tasks and previous socialization, certain resources such as family network may be experienced as support by some persons or as a burden by others (Noack, Hofer, Kracke \& Klein-Allemann, 1995).

To summarize, since social motivation or coping is always part of a more general system, it is not reasonable to compare single items but rather to look for patterns of the general system and possible differences between relevant patterns in different groups or in different contexts. Comparisons of means do not considerably improve our theoretical understanding while comparisons of functional relations contribute to a theory of individual action in social change.

\subsection{Functional Equivalence}

The methodological value of indicators in cross-cultural comparison does not only depend on the reliability, objectivity, and validity of single indicators but rather depends on the functional equivalence of indicators. For example, a certain questionnaire may have a different meaning for East and West German 
subjects on account of different meanings of wording, of scaling, of sequence of items etc. Therefore, the results for both samples are difficult to interpret. For instance, in interviews with West German mothers we presented among others a situation where the mother feels disturbed by her child during a telephone call. In our Indonesian study we exchanged the telephone situation against the situation of a discussion with shopkeeper from a vending car. For East German families who are not yet fully supplied with telephones it may be more appropriate to choose the mother's conversation with a visitor as a functionally equivalent situation.

Of course, these comments are not only related to questionnaires. They also apply to interviews. To give an example, the Adult Attachment Interview (AAI) (Main, 1990) is considered as a valid instrument to measure the quality of attachment of adults. In order to differentiate between the types of attachment (secure, avoiding, ambivalent), the quality of the responses by the interviewee are analyzed, e.g., with respect to coherence of answers, retrospective distortions etc.

It is unclear, however, whether incoherence in the answers by East and West German adults really means the same. For one thing, issues of cultural differences in self-presentation vis-a-vis a non-acquaintance should be taken into account. Furthermore, for East Germans it was much more unusual than for West Germans to give an interview for purely scientific reasons (apart from any political implication). Therefore, East German's interviewee's reluctance to report about the past may be based on several factors, e.g., uncertainty how much one could trust the interviewer; and irritation about perceived inconsistencies in one's biography (partly on account of political factors). These cognitions could be confounded and contribute to an interviewee's hesitations in reporting about the past. Therefore, beside issues of different strategies of self-presentation in East and West German people, issues of memory, self perception, perspective taking, and finally reporting about one's biography could invalidate the AAI for measuring attachment.

Other instruments measuring attachment such as "Separation Anxiety Test" (SAT, Klagsbrun \& Bowlby, 1976) consisting of several situations dealing with the topic of the child's separation from the mother may also be less valid for East as compared to West German samples. E.g., in East Germany mothers did not usually leave their child (their house) for several days (as one situation implies). On the other hand, separation between mother and child for several hours a day was a daily routine since most mothers in East Germany were working and left their child in day-care during their absence. Here, the functional equivalence of separation between mother and child in East and West Germany should be taken into account before generalizing on the basis of mean differences in attachment styles or before making any predictions on effects of attachment style on further development. 
To give another example: in our measurement of prosocial motivation we used the situation-specific questionnaire by Karylowski (1982) who had tested this instrument for Polish adolescents. However, some situations (dilemmas) from this instrument seem to be less relevant for East as compared to West German adolescents at least in these times of economic and other turbulence. However, indicators of prosocial behavior should be related to situations that are relevant in the respective contexts. Otherwise, different relevance of a situation as a potential prosocial dilemma should produce different responses due to different meanings. Therefore, differences in prosocial answers between East and West German youth basing on the same items must not necessarily indicate differences in their prosocial motivation. If the relevance of this situation was lower for East Germans, it is not surprising that East Germans score lower in prosocial motivation (cf. Trommsdorff \& Kornadt, 1995).

There are many more examples from comparative studies where questions of functional equivalence are simply not posed; thus differences or similarities between East and West Germans are difficult to interpret. This discussion on the functional equivalence of indicators in East and West Germany could be tied to Gordon Allports (1961) concepts of "common traits" vs. "personal dispositions". The "common traits" of the East and West Germans are e.g., culture, history, and language; the "personal dispositions" are the specific characteristics of East and West Germans based on the past 40 years of different political and economic development, including different socialization goals and practices. From this point of view, functional equivalence of specific indicators may be more easily specified.

However, it would be misleading if such indicators would only constitute "traits" and would not go beyond mere dispositional descriptions disregarding the meaning of such dispositions in a specific situational context for the activation of certain behavior. Thus, the functional meaning of certain dispositions for behavior should be the focus of comparative studies and the construction of relevant items.

Apart from problems of equivalence in instruments, it is highly questionable to what extent samples from East and West Germany can really be compared. To what extent is the basis for selection of samples equivalent? Just to mention an example: most studies on East German adolescents' values are based on samples from East Berlin. Of course, East Berlin is not at all representative of East Germany on account of the historical outstanding situation of East Berlin and the present special situation of this city. Furthermore, it is well known by now that strong regional differences exist between different parts of East Germany (e.g., Nauck \& Joos, 1996). Data on similarities or differences between East and West based on unspecific aggregates cloud intragroup and interindividual differences. These arguments also should be applied to the study of differences between cohorts (Huinink \& Mayer, 1993; Diewald \& Mayer, 1996). 
It is not easy to find suitable functionally equivalent subgroups. E.g., traditional socio-demographic indicators such as job, education etc. have a different meaning in East as compared to West Germany on account of the very different social structure in both parts for more than 40 years. The former GDR has produced primarily "Facharbeiter" ["skilled worker"], and social stratification (and mobility) had followed different rules in East and West Germany. To illustrate one of these difficulties: in our own study we try to control for regional equivalence of high school students from different regions in East and West Germany. However, this does not allow accounting for different social backgrounds since the educational system in East and West Germany was different until the unification. East as compared to West German adolescents who have been planning to get their "Abitur" before the unification differ in their family background beside personal history of socialization. When structural differences enter into the selection of samples, and similar groups of adolescents cannot be compared, it should at least be clarified whether and in which respect such samples are equivalent. This has to be remembered when interpreting results on similarities or differences between the samples.

When looking for functionally equivalent levels of social stratification, the degree of schooling may not be a relevant criterion for comparison. However, the fact whether this degree in principle enables the person to find a job offering secure income or giving the person the chance to take certain responsibilities for other people, or to pursue his/ her interests, may be a theoretically more relevant aspect for comparison. In our study we can at least compare adolescents in East and West Germany who have similar chances to find a job fulfilling these criteria. Therefore, one first has to study which educational degree gives them this chance and then compare adolescents that have similar starting conditions on this level. Of course, the selection of the level for comparisons depends on the question pursued. Therefore, the question of functional equivalence in sampling, in instruments, etc. can only be answered in a theoretical framework.

\subsection{Timing of Measurements}

The timing of measurements can also lead to false conclusions. Of course, the time of data collection should be similar in the samples to be compared (e.g., especially when significant events take place such as political elections, ending of school year etc.). However, something else has to be taken into account, especially when carrying out longitudinal research on effects of change on individual beliefs and behavior. One may find no differences between East and West German samples in the first and second measurement after the onset of change, but one may find significant changes in the third measurement that may disappear in the fourth measurement or the other way round. Whether these re- 
sults can be interpreted as effects of different effects of socialization, or effects of acculturation is unclear. From a life-span perspective, differences between people from East and West Germany at a certain time period are related to a specific developmental age - e.g., due to different onset of developmental tasks - and they may disappear at a later period of time. Or, such differences base on different processes and results of development related to a certain socio-political context, or more specifically, a certain fit between the individual person and his/her environment.

To give an example, it may be assumed that the rather smooth transformation of the school system including the successful adaptation process of the teachers may only represent one aspect of the change of the education system. Other aspects can only be observed after some time has elapsed, and e.g., the teachers find themselves confronted with a different cohort of pupils than there were used to during their past career. This experience may induce a more dramatic challenge for them than changes of the curriculum or other institutional changes.

If unexpected changes in occupational demands and other areas of life occur in the future, it is useful to keep track of such changes by empirically sound data. Such data would have to be comparative by taking into account changes over time and differences between contexts. Therefore, it may be quite fruitful for future research to make use of the specific historical past and ongoing changes in East Germany to test theoretically interesting relationships from a twofold comparative point of view: by collecting data at different points of time and from different (but comparable) cultural contexts. Thus it is too simple to start from the notion that comparisons between East and West German people at a certain point of time fulfills the requirements of a cross-cultural study in a quasi-experimental design.

The assessment of time in development is necessary in studies where timing of developmental tasks is compared, or where the onset of certain kinds of development, e.g., autonomy in adolescence, is studied (Trommsdorff, 1997 in press). Making use of further measurements beyond the preliminary first and second measurements can be useful in order to analyze the nature of developmental changes. This allows one to specify possible differences in the starting point for the onset of developmental change and of effects of social change in the process of individual development. For example, as Silbereisen and SchmittRodermund (1995) have pointed out, the time to achieve certain developmental tasks may be different for different cultural groups, even though the process of development and the developmental results are similar in these different groups. In our own studies comparing German and Japanese adolescents and young adults, we find significant similarities with respect to preference of values of youth culture until the early twenties. However, after finishing college or university, Japanese adolescents and young adults demonstrate significant changes in their attitudes and values, adopting adult roles and related values and thus 
abruptly distancing themselves from former libertarian and individualistic attitudes or adolescent role playing. Thus, certain values may be similar for a certain period of development and for adolescents from very different socio-cultural contexts; these-on the surface similar-values may then be integrated differently in young adults' further development during the life-course.

"Normative" developmental change should be differentiated from developmental changes related to a changing social context. Such studies should take into account the meaning of times of measurement. The related onset of individual changes can then be interpreted as individual adaptation to such changes and as part of development in context.

The quasi-experimental design is rarely made use of, mostly on account of methodological reasons. It is too simple to start from the notion that comparisons between East and West German people at a certain point of time fulfill the requirements of a cross-cultural study in a quasi-experimental design. In order to study the effects of the political system on personality development, data on relevant indicators should have been gathered in East and West Germany before the unification took place. Historical change took place in East Germany before the unification and thus influenced the socialization of people. This can be seen, e.g., in the increasing orientation of East German adolescents towards Western values during the eighties (e.g., Friedrich, 1991; Gensicke, 1996). Such liberalization trends in East Germany effected persons of different development age differently.

Therefore, studies on effects of the unification of the East German population should base on several points of measurement during_the transformation process, and also control for developmental age and socialization experiences before the turnabout. This means that data (basing on valid, objective and reliable methods) collected before the unification should be made available for comparative research, especially if such data are valid indicators of concepts which have been measured (by functionally equivalent instruments) in both parts of Germany, at the different periods of time, and for persons from different developmental age. It is hardly surprising, that these methodological requirements can hardly be fulfilled by the presently available data.

This difficulty surmounted by another problem. Many data collected before unification could have been used for comparisons, at least from the point of view of a less rigorous methodological level of aspirations. Extensive studies include data on development of children with different experience of early-institutionalized childcare. However, due to political and administrative reasons (including effects of the transformation) only few of these data are published (Weber, 1996; Zwiener, 1994), waiting for more extensive use, especially in longitudinal follow-up studies.

To summarize, confounding variables (partly due to historical change in East Germany, socio-cultural and political differences between East and West Ger- 
many, effects of developmental age etc.) question the validity of results from "cross-cultural" studies between East and West German populations, and of measurements of change in the East German population.

\subsection{Comparison Level for Data Analysis}

Differences between East and West Germany can be over- and underestimated according to the kind of comparison. Different anchors for comparison can lead to different conclusions and also to misinterpretations of differences and similarities.

Inter- and intra-group comparisons. Intra-cultural variances need to be taken into consideration. Thus it has to be recognized that the former GDR has not been a homogenous society. First, this can be seen by the enormous number of East Germans fleeing to West Germany until 1961 when this was abruptly made impossible. Therefore, it is necessary to differentiate between different people: those who really identified with the system and those who were very apolitical in their attitudes, and the various shades between such poles. The discrepancies between the political system and underlying ideology on the one hand and multiple niches for individual adaptation including the imitation of Western life styles and values on the other hand make it quite difficult to predict which aspects of the former GDR have influenced the way of thinking of certain groups.

Differences between East and West Germans on the aggregate level may be smaller than differences between regions or certain social groups in East and in West Germany. Furthermore, it has been shown that difference between East and West Germans at any point of time are significantly smaller than differences between both groups and another Western population, e.g., the French. This is illustrated by data on educational goals of East Germans and French people (cf. Gensicke, 1996). French people value orderliness, conformity and discipline to a significantly higher degree than East and West Germans (while the difference between East and West Germans is relatively small).

Effects of the unification. In several studies the question is posed whether after the unification, East Germans have shifted into the direction of West Germans values, or whether West Germans have shifted - thus inducing more similarity. So far, it seems that both, East and West Germans have shifted in the same direction in some respects, e.g., the preference for security, so that differences between them have not declined. In other aspects, East Germans have shifted more into the direction of West Germans (e.g., less value of conformity) (cf. Meulemann, 1995; 1996).

Whether changes in individual values, preferences and behavior are an effect of the transformation cannot be answered when the baseline for comparison is the onset of unification. Instead, the situation before the onset of unification 
should be taken into account, too. For instance, social and value changes with respect to individuality and hedonism which have been taking place in the former GDR in the eighties may be a relevant precondition for the effectiveness of significant changes into the direction of "post-modern" values after the unification (Schnabel et al., 1994). Existing trends and tendencies, especially in the younger Generation in East Germany may have reinforced the effects of political and social change during the transformation process. If such trends of hedonism and individualism had not existed before the unification, qualitatively different patterns of value change may have occurred.

Sharing the same socio-political system is no sufficient condition to predict that East and West Germans will become increasingly similar to each other e.g., with respect to "postmaterialist" values. East Germans have chosen Westem standards for consumption, and they regard differences in economic conditions as frustrating. With respect to the infrastructure (housing; traffic; communication) satisfaction ratings during the past five years show discrepancies between "objective" improvement and subjective ratings (Zapf, 1994).

It is difficult to infer increasing value similarity since increasing acceptance of dominant West German values and attitudes must not necessarily mean the acceptance of "post-materialist" orientations. Some "postmaterialist" values have a long tradition in East Germany, such as secularization; other "post-modern" values are still discrepant to East German value orientations, such as individualistic hedonism. Though value orientations of East and West Germans now coincide in some areas, in others discrepancies continue to exist (cf. Meulemann, 1995; 1996).

Another misinterpretation of similarities between East and West Germans (on account of effects of transformation process on value change) is based on disregarding the base line and the product of change by only focusing on the direction of change. Misinterpretation of similarities and differences usually result from simple mistakes, e.g., ignoring processes of change.

\section{Similarities or Differences in East and West Germany: A Cross-cultural and Acculturation Perspective}

\subsection{What is the Situation Like Today?}

While the situation directly after the turnabout was as described above - testing for theoretically interesting relationships by making use of cross-cultural comparisons and a quasi-experimental setting - this enthusiasm has gone today.

This is not only due to the methodological problems as described above including difficulties in finding valid indicators of relevant social and psychological variables. This is also due to the generalized belief that after several years of 
sharing the same political and economic system, the transformation should be terminated, and not many differences between West and East Germany should have remained. From this point of view it seems questionable whether it is still worthwhile to study the effects of social change on the one hand and the generalizability of certain theoretically interesting relationships on the other hand by comparing East and West German samples.

Comparisons between south and north German regions seem to account for more differences than comparisons between East and West Germany (e.g., with respect to value of children) (Nauck \& Joos, 1996). However, even though intra-cultural differences seem to affect certain attitudes, and even though the transformation process is said to be terminated, it cannot be denied that it will take several more years before the economic, social and psychological situation in East and West Germany will be about the same. Though the time of dramatic change in institutions is over, the after-effects of such changes still remain. And even more important, changes in latent variables may transform into change of manifest variables. Some socio-political changes induce observable changes on the individual level only after some time has passed (sleeper effects). Sometimes, a certain constellation of variables is necessary to activate latent variables that, in turn, affect actual changes in individual attitudes.

Accordingly, it has to be assumed that consequences of the transformation have not yet come to an end, and that underlying contextual differences between East and West Germany will continue to exist and may have some impact on certain developmental processes. The kind of impact should, of course, be specified. Whether the results of such impact will bring about similarities or differences in personality development remains open for the empirical analyses. While there may be good reasons to compare other German regions which differ with respect to economic and political structure, this does not provide a sufficient reason to stop thinking about and collecting data on the processes of social change in East and West Germany, and the impact of such change on individual development, and vice versa.

To summarize, the methodological problems regarding similarities and differences between two cultural groups demonstrate how important it is to study individual development in the context of socio-political changes. This brings us close to a more theoretical approach to the study of similarities and differences. When the main goal is to study individual development in changing social contexts, the functional equivalence of developmental base lines, of developmental processes, and of developmental outcomes should be investigated. This may improve our understanding of differential ways of development in context. 


\subsection{Socialization and Development in Various Contexts}

Research on the processes of "transformation" in East Germany and people's adjustment to dramatic socio-political changes cannot stop with asking whether and at which period of time East and West Germans are similar or dissimilar in thinking and behavior. From the point of view of individual development in changing social contexts, the following questions are relevant: How was the socialization experience in both parts of Germany, and how were the persons like who had to deal with the drastic socio-political changes? How were these sociopolitical changes experienced and coped with? Will these psychological experiences stimulate processes of acculturation of East Germans? Will ongoing change and interactions with East Germans also affect West Germans? Will East Germans' adaptations to beliefs and behavior of West Germans be functional or dysfunctional for coping with risks and change?

From a mechanistic view of development and learning, different socio-political systems - e.g., socialization in a context demanding conformity to party rules vs. socialization in a free democratic system - provide a lot of impact to induce different developmental outcomes. On the other hand, similarities between East and West German contexts increase after the unification, thus, providing socialization conditions for similar developmental outcomes. However, on the basis of a bulk of recent, especially longitudinal and cross-cultural studies, this mechanistic view can hardly be seriously defended any more. Empirical studies and theoretical approaches support the view of development of the person as a process of individual action (Lerner, 1991) and interaction in certain developmental niches (Super \& Harkness, 1986) or in different socio-cultural contexts (Kinderman \& Valsiner, 1995).

Furthermore, differentiations with respect to socialization contexts in the former GDR have to be taken into account. An example for the need of differentiation is that formal education in kindergarten and schools in the former GDR was complemented by many informal socialization experiences such as the intimate family environment, informal friendship groups and, later, informal social networks at the work place. Such informal groups could provide a source for emotional security, for solidarity, and for social support in affairs of everyday life. The effects of such informal socialization had not necessarily been in line with the goals of formal socialization. Private social networks constituted developmental niches in which official socialization programs could be disregarded. Thus, East Germans have learned to differentiate between private and public acceptance of rules and norms (overt and covert compliance). Even though little is known about the ways in which inconsistencies between informal and formal socialization were experienced, socialization experiences were presumably not uniform and their effects cannot been generalized for the East or West German population. 
Starting from a life-span perspective of development, differentiations with respect to developmental age and cohorts must be taken into account (cf. Baltes \& Baltes, 1990). Such views consider effects of age and cohort based on different socialization experiences and developmental tasks when studying the effects of the drastic socio-political change on individual thinking and behavior. E.g., the degree of selective investment during one's life course is different for different cohorts.

\subsection{Dealing with Social Change}

Interindividual differences. East Germans who have expected to work life long and who are now facing life-long unemployment now have to cope with the fact that past investments into work life are no longer useful. They have to invest special resources and achieve new competencies in order to cope with such unexpected changes in their lives. Competencies and expectations that have been built up in a certain socio-political environment are investments for the future and part of one's identity. When such resources become futile and related expectations break down, identity must be redefined. In order to predict individual's reaction to social change, developmental age, gender, regional and social contexts, and related resources (social, cognitive, emotional) become relevant. East Germans are adapting to the drastic socio-political changes in various ways and on the basis of certain resources established during past socialization experience.

After the unification the disruption of informal social networks in school, at the workplace and in the neighborhood has induced experiences of insecurity and loss of control; this may have contributed to complaining about disruptions of solidarity as can be seen from surveys on value change (cf. Gensicke, 1996). However, family orientation was quite stable and has served as a successful buffering factor in East Germany (Trommsdorff \& Chakkarath, 1996).

Inter-vs. intra-cultural differences. Some persons who were successful during the former GDR (party members holding responsible functions in governmental organs) were quite successful after the collapse as biographical interviews by Pirker, Lepsius, Weinert \& Hertle (1995) demonstrate. However, people lacking occupational success in the former GDR as compared to successful persons showed less coping abilities: they hold a more external control orientation and less optimism (cf. Diewald, Huinink \& Heckhausen, 1996). Therefore, intragroup differences in coping should be expected. Some intra-cultural differences could well become larger than inter-cultural differences between East and West Germans. It is too simple to only focus on East-West comparisons.

According to the ecological model of Bronfenbrenner (1979), at least contexts on the meso level such as school system etc. should be taken into account. Re- 
cent studies on students ${ }^{\prime}$ attitudes and achievement after the unification demonstrate that East-West-differences diminish while intra-regional differences increase. Longitudinal studies by Schnabel, Baumert and Roeder (1996) carried out directly after the unification (1991/92) showed a less positive self-concept and higher stress experience in school (e.g., fear of failure, helplessness) of East as compared to West German students at the beginning of the school year. At the end of the school year, these differences between different types of schools (gymnasium etc.) (which could be observed at the beginning of the school year) significantly increased. The same study showed an increase in gender differences in East Germany with respect to preference and achievement in natural sciences, in the same direction as was the case in West Germany, while at the beginning of the transformation only gender differences in interest but not in achievement occurred in East Germany.

Though it is unclear which aspects of transformation have contributed to these changes (with respect to self concept, perceived stress and achievement), this study clearly demonstrates that differences and similarities between East and West Germany depend on more specific socialization conditions which become effective during the transformation of the East German school system. These contribute to the growth of gender similarities in East and West Germany and at the same time they contribute to an increase in gender differences and differences of the school system in East Germany.

Inter-cultural differences in coping strategies. On the other hand, East German people have adopted specific ways of coping which are different to West German coping styles. Studies on aging people in East and West Germany show more "successful" aging of East German females. East German 60 year olds, especially females are more satisfied with their life than the same cohort of West Germans. This is presumably not only an effect of the improved economic situation of East German aging people. Especially East German females who have mostly been working in the labor force presumably base their judgments on experiences of independence and success in overcoming economic and political difficulties in the past. Therefore, it is not surprising that East German women report more internal control than a comparable West German cohort (Roether \& Kunze, 1996).

In line with the general value system prevailing in a culture, certain cognitive and behavioral systems are socialized; as long as they prove to be functional for the given situational demands these styles are reinforced. Accordingly, culturespecific problem solving strategies develop which base on culture-specific perceptions and evaluations defining which situation constitutes which kind of problem. Therefore, an objectively defined situation and related problems are perceived and dealt with differently according to differences in prevailing beliefs and values (Essau \& Trommsdorff, 1996). Do East and West Germans differ in the subjective perception and interpretation of problematic situations? 
East Germans are presumably more sensitive to uncertainty, after having been socialized in a rather closed system where their future could be clearly anticipated and material security was ascertained. In this case, the need for uncertainty reduction may be more prominent in perceiving, evaluating and dealing with specific problems related the ongoing changes.

Differences in abilities and preferences between East and West German people should be functional when dealing with different environmental demands. As recent studies show East and West Germans seem to use different cognitive styles to deal with uncertainty. This is reflected in differential preference for values of work or personal security for East as compared to values of self-reliance, personal autonomy etc. in West German subjects. Strohschneider (1996) summarizes several studies on differences in problem solving in East and West Germany. East as compared to West Germans prefer a deductive analytical thinking style in a causal-deterministic and hierachically organized framework; they try to find a general principle according to which the problem can be solved, and they engage in group problem solving by making use of group solidarity and harmony. This kind of problem solving is useful for specific kinds of problems (limited complexity, no time pressure, little change over time). For these kind of problems the West German's more inductive and flexible but also less complete and less persistent problem solving strategy would be inadequate while it would be useful for highly complex and rapidly changing problems.

Empirical data by Dörner (1996) on better tactical than strategic (planning) abilities of East as compared to West German students can be interpreted to demonstrate that different abilities and cognitive schemata have been learned according to the prevailing socialization system. The functional utility of these styles must be seen in relation to the situational demands and respective quality of problems to be solved. Only then predictions can be made about successful problem solving. For coping behavior, the same argument may be valid. Therefore, studies comparing East and West German people should specify the functional meaning of the criteria under study, e.g., the functional relevance of certain values, preferences, or abilities with respect to given situational demands.

To summarize, in some respect effects of transformation are minimizing differences between East and West Germans, and widening differences between certain groups (e.g., females and males, students with different schooling). Besides decreasing intergroup variance an increasing intragroup variance can be observed.

Intra-individual changes in attitudes. Enormous changes on the aggregate level in East Germany after the unification are more obvious than intra-individual changes partly induced by coping. This is a process of taking time and developing in several stages, and this may be different for people from different developmental age. For instance, some persons who were strongly disappointed after the turn-about and who retreated into privacy, may now become aware of 
the fact that the present situation has improved and is providing chances for one's goal achievement. They may become aware of ways to actively participate in ongoing changes by investing abilities and specific competence. Others may have viewed the turn-about with high optimism and now become aware of difficulties, starting to cope with disappointment at a much later stage.

No longitudinal studies on such intra-individual changes are available. Therefore, it is highly speculative to attribute the turn-about to psychological variables (such as the need of the people to change the system), and to generalize about the East German attitudes before the turn-about. On the aggregate level, one can see from surveys carried out immediately after the unification that East Germans were highly in favor of the market economy but then decreased their acceptance continuously.

Certain similarities in attitudes between East and West Germans were followed by a continuos increase of differences which originated from East Germans increasing ambivalence (decreased acceptance of market economy from 77 \% in 1990 to about almost $50 \%$ in 1992; and in 1995 to about $1 / 3$. Surveys also indicate East German's decreased acceptance of the German government: more than $50 \%$ do not consider the (West) German system as just (see summaries of Pollack, 1997; Montada \& Dieter, 1996). East Germans seem to accept the West German system less than West Germans on account of experienced disillusions. At the same time, the former GDR is evaluated more positively by East Germans than some years ago. In 1995 the number of areas for which East Germans see the former GDR (especially in the areas of child care, education, health, social security and job security) in a more positive light than the West German system has increased (see Montada \& Dieter, 1996). Such changes of attitudes on the aggregate level have to be differentiated when studying adaptation to the new political system. E.g., younger people in East Germany are increasingly rejecting political institutions (Seifert, Rose \& Zapf, 1993). However, it remains still unclear what the process at the individual level was like.

At the aggregate level, certain similarities between East and West Germans that could be demonstrated directly after the unification have disappeared. It remains to be tested whether this is an indicator of increased distancing of East German people from West Germans. More precisely, does this indicate that East German's reject perceived West German negative beliefs about East Germans and the former GDR? Again, this process is related to phenomena of social identity and intergroup evaluation. In case that East Germans view themselves as being the target of negative stereotyping by West Germans this may induce a higher readiness to overestimate the former achievements of the GDR, and to devalue the achievements of the West German system. In line with theories of intergroup judgement and the enhancement of a positive social identity, this tendency can serve the need to achieve a positive social identity. This ten- 
dency can also serve the need to regain a feeling of justice that seems to have been threatened during the last years (Montada \& Dieter, 1994; 1996).

To summarize, social changes do not have the same meaning for different persons. Sociopolitical changes as are presently occurring in East Germany are experienced differently by different groups and at different periods of time. For some people, and for a certain period of time, such changes mean critical life events and serious risks, or they mean challenges and chances, or they mean both.

It is not clear whether adapting to the Western values and mentality is really useful for East Germans' successful participation in the present German society, or whether certain attitudes which were socialized during the former GDR provide better conditions for successful coping. The preference for values such as high discipline and orderliness may allow East Germans to cope successfully with new developmental tasks. This preference may help to be successful in work contexts and to succeed in competition with West German applicants, or to save one's identity and life satisfaction. The same advantages could be expected from specific problem-solving strategies like tactical competence that may be more useful in certain situations than strategic competence. Thus, the search for functional equivalence of indicators should go beyond methodological considerations and deal with theoretical refinements.

\section{Outlook}

Unification sometimes has been seen oversimplified as a quasi-natural experimental condition allowing one to systematically compare developmental outcomes of people from two different and partially similar socialization contexts, and to study how the changing East German context affects further individual development. However, when taking into account the variety in person's beliefs and situational options before the time of the turn-about of the GDR, and the massive multifaced changes after the collapse of the GDR on many levels of people's environment, there is little chance to strictly control effects of the transformation on individual lifes of East Germans. The methodological requirements for testing "experimentally" induced effects are not met.

It seems more useful to start from an ecological model approach (Bronfenbrenner, 1979) and take a macro- and meso-levels comparative view which conceives of East and West Germany as different contexts for individual development. Then the question arises, how East Germans have been experiencing the transformation into the different socio-political and cultural West German system which was glorified by some and rejected by others, and which disappointed many or which matched with other people's subjective expectations. 
The subjective experience of the different pluralistic, democratic and individualized system partly is a result of past socialization and present options; these constitute the preconditions for the way adaptations and coping with problems stemming from this new context are pursued.

What does a successful "acculturation" of East Germans in interaction with the West German majority group mean: assimilation, integration, separation, or isolation? Is the process of acculturation related to certain changes in East Germans' attitudes and behavior that then decrease existing differences between the two groups? Would such changes imply more psychological unification due to reduced discrepancies, or does the psychological unification rather depend on "objective" degrees of similarities in certain personality variables, attitudes and behavior style? Would East Germans give up some of previously established advantages for coping with problems, in case of continued assimilation to West German's beliefs, attitudes and behavioral styles?

As we have seen above, some of the beliefs and abilities acquired during socialization in the former GDR should be quite useful for successful problem solving. Therefore, it may be more rational to preserve certain beliefs and abilities. For example, the belief in internal control and satisfaction in case of aging women, or more tactical competence are qualities acquired during socialization in the former GDR; these may be important resources for coping with a changing system. Thus, it is worthwhile to study which kind of differences may have functional value for which groups of East Germans in the long run (Trommsdorff, 1996b). Again, the person's developmental age and social situation will affect such individual processes of coping.

Thus, from a psychological point of view, the variety in past socialization and related coping strategies of East Germans are one aspect to caution against testing for similarities and differences between East and West Germans on an aggregate level. From a methodological point of view, it has to be questioned whether the methodological requirements of functional equivalence are fulfilled in such studies. From a theoretical point of view it has to be specified under which conditions social change allows for advantages in individual development.

Therefore, studies on differences or similarities between East and West Germans should take into account (a) methodological problems of cross-cultural research, (b) differential socialization experiences, and (c) different resources such as strategies of coping with change. Adaptation to the dramatic socio-political changes does not follow simple rules of social learning but rather depends, among other factors, on individual and social constructions of identity and social change. It is assumed that these processes take time and follow certain nonlinear sequences. Studies of differences and similarities of East and West German's thinking and behavior should thus rather focus on the functional value of specific individual differences and similarities in the process of individual development in a changing social context. The advantage of such studies 
could be to build on a theory of interactive processes of individual development and social change.

\section{References}

ALLBUS (1994). Allgemeine Bevölkerungsumfrage der Sozialwissenschaften (ALLBUS). Einzelstudie 1994. Zentralarchiv für empirische Sozialforschung an der Universität zu Köln und Zentrum für Umfragen, Methoden und Analysen (ZUMA). Mannheim.

Allport, G. W. (1961). Patterns and growth in personality. New York: Holt, Rinehart \& Winston.

Baltes, P. B. \& Baltes, M. M. (1990). Psychological perspectives on successful aging: The model of selective optimization with compensation. In P. B. Baltes \& M. M. Baltes (Eds.), Successful aging: Perspectives from the behavioral sciences (pp. 1-34). New York: Cambridge University Press.

Bronfenbrenner, U. (1979). The ecology of human development. Experiment by nature and design. Cambridge/MA: London, UK: Harvard University Press.

Diewald, M., Huinink, J. \& Heckhausen, J. (1996). Lebensverläufe und Persönlichkeitsentwicklung im gesellschaftlichen Umbruch. Kohortenschicksale und Kontrollverhalten in Ostdeutschland nach der Wende. Kölner Zeitschrift für Soziologie und Sozialpsychologie, 48, 219-248.

Diewald, M. \& Mayer, K. U. (1996). Zwischenbilanz der Wiedervereinigung. Strukturwandel und Mobilität im Transformationsprozeß. Opladen: Leske + Budrich.

Dörner, D. (1996). Waldbrand: Handeln in Krisensituationen. In S. Strohschneider (Ed.), Denken in Deutschland (S. 49-58). Bern: Huber.

Elder, G. (1997). Studying social change in young lives. In L. Crockett \& R.K. Silbereisen (Eds.), Negotiating adolescence in times of social change. Cambridge: Cambridge University Press. (In press)

Essau, C. \& Trommsdorff, G. (1996). Coping with university-related problems: A cross-cultural comparison. Journal of Cross-cultural Psychology, 27, 315-328.

Flanagan, C. (1995). Reframing concepts of development in the context of social change, In P. Noack, M. Hofer, \& J. Youniss (Eds.), Psychological responses to social change (pp. 2336). Berlin/New York: Walter de Gruyter.

Frese, M. \& Hilligloh, S. (1994). Eigeninitiative am Arbeitsplatz im Osten und Westen Deutschlands: Ergebnisse einer empirischen Untersuchung. In G. Trommsdorff (Ed.), Psychologische Aspekte des sozio-politischen Wandels in Ostdeutschland (pp. 200-216). Berlin/New York: Walter de Gruyter.

Friedlmeier, W. (1995). Subjektive Erziehungstheorien im Kulturvergleich. In G. Trommsdorff (Ed.), Kindheit und Jugend im Kulturvergleich (pp.43-64). Weinheim: Juventa.

Friedlmeier, W. (1996). Psychology's contributions to the study of the effects of socio-political changes on the individual. Polish Quarterly of Developmental Psychology, 2, 145-156.

Friedrich, W. (1991). Zum Wandel der Mentalität ostdeutscher Jugendlicher seit den 70er Jahren. In P. Büchner \& H.-H. Krüger (Eds.), Aufwachsen hüben und drüben. Deutschdeutsche Kindheit und Jugend vor und nach der Vereinigung (pp. 225-234). Opladen: Leske + Budrich. 
Gensicke, T. (1996). Von der Transformation zur Integration. Die Ostdeutschen an der Schnitstelle zwischen individueller Anpassung und Vergeselischafung im neuen Deutschland. Speyer: Hochschule für Verwaltungswissenschaften. (Unpublished Dissertation)

Hansburg, H.G. (1972). Adolescent separation anxiety. A method for the study of adolescent separation problems. Illinois: Charles $\mathrm{C}$. Thomas.

Huinink, J. \& Mayer, K. U. (1993). Lebensverläufe im Wandel der DDR-Gesellschaft. In H. Joas \& M. Kohli (Eds.), Der Zusammenbruch der DDR (pp. 151-171). Frankfurt a. M.: Suhrkamp.

IFD Allensbach (1991). Fortschritte in Ostdeutschland. Allensbacher Berichte 9, Allensbach.

Joas, H. \& Kohli, M. (Eds.) (1993). Der Zusammenbruch der DDR. Frankfurt a. M.: Suhrkamp.

Karylowski. J. (1982). Two types of altruistic behavior. Doing good to feel good or to make the other feel good. In V. J. Grzelak \& J. Derlega (Eds), Cooperation and helping behavior. Theories and research (pp. 397-412). New York: Academic Press.

Kindermann,T. \& Valsiner J. (Eds.). (1995). Development of person-context relations. Hillsdale, NJ: Erlbaum.

Klagsbrun, M., \& Bowlby, J. (1976). Responses to separation from parents: A clinical test for young children. Projective Psychology, 21, 7-29.

Kornadt, H.-J. (1996). Erziehung und Bildung im Transformationsprozeß. In S. E. Hormuth, W. R. Heinz, H.-J. Kornadt, H. Sydow \& G. Trommsdorff (Eds.), Individuelle Entwicklung, Bildung und Berufsverläufe. Berichte zum sozialen und politischen Wandel in Ostdeutschland der $K S P W, B d .4$ (pp. 201-272). Opladen: Leske + Budrich.

Lerner, R. M. (1991). Changing organism-context relations as the basic process of development: A developmental contextual perspective. Developmental Psychology, 27, 27-32.

Main, M. (1990). Cross-cultural studies of attachment organization: Recent studies, changing methodologies and the concept of conditional strategies. Human Development, 33, 48-61.

Mayer, K. U. (1993). Vereinigung soziologisch: Die soziale Ordnung der DDR und ihre Folgen. Berliner Journal für Soziologie, 3, 307-321.

Meulemann, H. (1995). Aufboltendenzen und Systemeffekte. Eine Übersicht über Wertunterschiede zwischen West- und Ostdeutschland. Politik und Zeitgeschichte. (Beilage zur Wochenzeitung “Das Parlament"), 11, 21-33.

Meulemann, H. (1996). Werte und Wertewandel: Zur ldentität einer geteilten und und einer wieder vereinigten Nation. Weinheim: Juventa.

Montada, L. \& Dieter, A. (1996). Wahrgenommene Ungerechtigkeiten im Prozeß der Wiedervereinigung. Paper presented at the "Symposium des Zentrums für Gerechtigkeitsforschung" on "Veränderungserfahrungen im wiedervereinigten Deutschland: Gerechtigkeitserleben und Befindlichkeiten" University of Potsdam, Germany, 1996.

Nauck, B. \& Joos, M. (1996). Wandel der familiären Lebensverhältnisse von Kindern in Ostdeutschland. In G. Trommsdorff (Ed.), Sozialisation und Entwicklung von Kindern vor und nach der Vereinigung. Beiträge zum Bericht "Individuelle Entwicklung, Bildung und Berufsverläufe im Transformationsproze " der KSPW, Bd. 4.1 (pp. 243-298). Opladen: Leske + Budrich.

Noack, P, Hofer, M., Kracke, B. \& Klein-Allermann, E. (1995). Adolescents and their parents facing social change: Families in East and West Germany after unification. In P. Noack, M. Hofer, \& J. Youniss (Eds.), Psychological response to social change (pp. 129 149), Berlin/New York: Walter de Gruyter.

Noelle-Neumann, E. (1995). Deutschland im Frühjahr 1995. Die Muster wechselseitiger Beeinflussung von Ost- und Westdeutschen. Allensbach: Institut für Demoskopie. 
Pirker, T., Lepsius, R. M., Weinert, R. \& Hertle, H.-H. (1995). Der Plan als Befehl und Fiktion. Wirtschaftsführung in der DDR. Opladen: Westdeutscher Verlag.

Pollack, D. (1997). Das Bedürfnis nach sozialer Anerkennung. Der Wandel der Akzeptanz von Demokratie und Marktwirtschaft in Ostdeutschland. Politik und Zeitgeschichte (Beilage zur Wochenzeitschrift “Das Parlament”), 13, 3-14.

Reissig, R. (Ed.). (1993). Rückweg in die Zukunft. Über den schwierigen Transformationsprozess in Ostdeutschland. Frankfurt/New York: Campus.

Roether, D. \& Kunze, H. (1995). Lebenssituation alter Menschen - Ein Ost-West-Vergleich. Zeitschrift für Gerontopsychologie und -psychiatrie, 8, 263-272.

Schmidt, H.-D. (1996). Erziehungsbedingungen in der DDR: Offizielle Programme, individuelle Praxis und die Rolle der Pädagogischen Psychologie und Entwicklungspsychologie. In G. Trommsdorff (Ed.), Sozialisation und Entwicklung von Kindern vor und nach der Vereinigung. Beiträge zum Bericht "Individuelle Entwicklung, Bildung und Berufsverläufe im Transformationsprozeß" der KSPW, Bd. $4 . I$ (pp. 15-171). Opladen: Leske + Budrich.

Schmidt, H. D. \& Heckhausen, J. (1994). Entwicklungspsychologische Transformationsforschung - Ziele, Grundlagen, Konsequenzen. In G. Trommsdorff (Ed.), Psychologische Aspekte des sozio-politischen Wandels in Ostdeutschland (pp. 43-49). Berlin: DeGruyter.

Schmitt, M. \& Janetzko, E. (1994). Verantwortlichkeitsüberzeugungen bei Ost- und Westdeutschen. In G. Trommsdorff (Ed.), Psychologische Aspekte des sozio-politischen Wandels in Ostdeutschland (pp.169-179). Berlin/New York: Walter de Gruyter.

Schnabel, K., Baumert, J. \& Roeder, P. M. (1994). Wertewandel in Ost und West - Ein Vergleich von Jugendlichen und Erwachsenen in den neuen und alten Bundesländern. In G. Trommsdorff (Ed.), Psychologische Aspekte des sozio-politischen Wandels in Ostdeutschland (pp.77-93). Berlin/New York: Walter de Gruyter.

Schnabel, K., Baumert, J. \& Roeder, P. M. (1996). Zum Wandel des Schulsystems in den neuen Bundesländern. Neue Sammlung: Vierteljahres-Zeitschrift für Erziehung und Gesellschaft, 36, 531-544.

Seifert, W., Rose, R. \& Zapf, W. (1993). Ökonomische Verhaltensweisen und politische Einstellungen im vereinten Deutschland. Bericht des Wissenschaftlichen Zentrums Berlin (pp.93-109). Berlin: Wissenschaftliches Zentrum Berlin.

Silbereisen, R. K. \& Schmitt-Rodermund, E. (1995). Akkulturation von Entwicklungsorientierungen jugendlicher Aussiedler. Bedeutung von Familie und Peers. In G. Trommsdorff (Ed.), Kindheit und Jugend in verschiedenen Kulturen (pp.263-292). Weinheim/München: Juventa.

Strohscheider, S. (1996). Denken in Deutschland. Stuttgart: Enke.

Super, C. M. \& Harkness, S. (1986). The developmental niche: A conceptualization at the interface of child and culture. International Journal of Behavioral Development, 9, 545-569.

Tajfel, H. \& Turner, J. C. (1986). The social identity theory of intergroup behavior. In $S$. Worchel \& W. Austin (Eds.), Psychology of intergroup relations, 2nd edition (pp.7-24). Chicago: Nelson-Hall.

Trommsdorff, G. (1994). Psychologische Probleme bei den Transformationsprozessen in Ostdeutschland. In G. Trommsdorff (Ed.), Psychologische Aspekte des sozio-politischen Wandels in Ostdeutschland (pp.16-42). Berlin/New York: Walter de Gruyter.

Trommsdorff, G. (1995a). Individuelles Erleben und sozio-politischer Wandel. Einstellungen zu Europa, Deutschland und der Region bei Bewohnern in französischen und schweizerischen Grenzgebieten. Universität Konstanz, Unpublished manuscript.

Trommsdorff, G. (1995b). Identitätsprozesse im kulturellen Kontext und im sozialen Wandel. In H. Sahner (Ed.), Transformationsprozesse in Deutschland (pp.117-148). Opladen: Leske + Budrich. 
Trommsdorff, G. (1995c). Social change in East and West Germany: A subjective representation approach. Paper presented at the Anglo/German Meeting: "Adversity and challenge in the life course in the new Germany and England”, London, 1995.

Trommsdorff, G. (1996a). Werte und Wertewandel im kulturellen Kontext aus psychologischer Sicht. In E. Janssen, U. Möhwald \& H. D. ÖIschleger (Eds.), Gesellschaften im Umbruch? Aspekte des Wertewandels in Deutschland, Japan und Osteuropa. Monographien des Deutschen Instituts für Japanforschung der Phillipp-Franz-von-Siebold-Stiftung, Band 15 (pp. 13-40). München: Iudicium Verlag.

Trommsdorff, G. (1996b). Transformationsforschung als Herausforderung für die Psychologie. Berliner Journal für Psychologie, 3, 317-324.

Trommsdorff, G. (1997). Effects of social change and individual development: The role of social and personal factors and the timing of events. In L. Crockett \& R.K. Silbereisen (Eds.), Negotiating adolescence in times of social change. Cambridge: Cambridge University Press. (In press)

Trommsdorff, G. \& Chakkarath, P. (unter Mitarbeit von P. Heller) (1996). Kindheit im Transformationsprozeß. In S. Hormuth, W. R. Heinz, H.-J. Kornadt, H. Sydow \& G. Trommsdorff, (Eds.), Individuelle Entwicklung, Bildung und Berufsverläufe KSPW Bd. 4 (pp. 22-87). Opladen: Leske + Budrich.

Trommsdorff, G., \& Kornadt, H.-J. (1995). Pro- and antisocial motivation of adolescents in Eastern and Western Germany. In J. Youniss (Eds.), New directions for child development, Number 70: After the wall: Family adaptations in East and West Germany (pp.39-56). San Francisco, CA: Jossey-Bass.

Weber, C. (1996). Erziehungsbedingungen im frühen Kindesalter in Kinderkrippen vor und nach der Wende. In G. Trommsdorff (Ed.), Sozialisation und Entwicklung von Kindern vor und nach der Vereinigung. Beiträge zum Bericht "Individuelle Entwicklung, Bildung und Berufsverläufe im Transformationsproze $"$ " der KSPW, Bd. 4.1. (pp. 173-241). Opladen: Leske + Budrich.

Wottawa, H. (1994). Veränderungen und Veränderbarkeit berufsrelevanter Eigenschaften im Ost-West-Vergleich. In G. Trommsdorff (Ed.), Psychologische Aspekte des sozio-politischen Wandels in Ostdeutschland (p.216-229). Berlin/New York: Walter de Gruyter.

Zapf, W. (1993). Die DDR 1989/1990 - Zusammenbruch einer Sozialstruktur?. In H. Joas und M. Kohli (Eds.), Der Zusammenbruch der DDR (pp. 29-48). Frankfurt a.M.: Suhrkamp.

Zapf, W. (1994). Die Transformation in der ehemaligen DDR und die soziologische Theorie der Modernisierung. Berliner Journat fur Soziologie, 3, 295-305.

Zwiener, K. (1994). Kinderkrippen in der DDR. Materialien zum 5. Familienbericht/Bd. 5 des DJI. München/Weinheim: Juventa. 